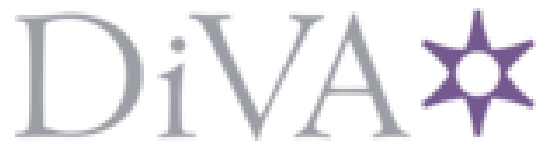

http://www.diva-portal.org

This is the published version of a paper published in First Monday.

Citation for the original published paper (version of record):

Hällgren, C. (2019)

Crowdsourcing identities: On identity as an existential practice mediated by contemporary digital technology

First Monday, 24(1): 8112

https://doi.org/10.5210/fm.v24i1.8112

Access to the published version may require subscription.

N.B. When citing this work, cite the original published paper.

Permanent link to this version:

http://urn.kb.se/resolve?urn=urn:nbn:se:umu:diva-154797 
First Monday, Volume 24, Number 1 - 7J anuary 2019

f $\mathrm{i}$ (3) $s+m \boldsymbol{x} \tilde{\mathbf{n}} \mathbf{d} @ \mathbf{\eta}$

PEER-REVIEWED JOURNAL ON THE INTERNET

\title{
Crowdsourcing identities: On identity as an existential practice mediated by contemporary digital technology by Camilla Hällgren
}

\begin{abstract}
The purpose of this article is to outline crowdsourcing identities as one way to think about humans' making of identity when practiced in conditions mediated by contemporary digital technologies. It brings together human practices, theory and technology and draws on perspectives of existentialism, social constructivism, technology and ideas about crowdsourcing. Humans' making of identity is considered a practice that concerns continuous requests and answers about existential matters of being, becoming and belonging: Who am I? How do I appear to others? Who can I be and become? Where do I belong? In that sense, it is a relational and social practice that is essential to exist as someone - rather than as no one. However, contemporary digital technologies such as social media are not considered essential to this practice. Technologies are thought of as mediating conditions where, for instance, social interactions about existential matters, such as the making of identity, can be practiced in ways that extend on what were possible in predigital times. In multimodal, multidirectional, collaborative and networked ways humans can represent, communicate, gather information and also engage online crowds of others in continuous requests and answers about being, becoming and belonging; Who am I? How do I appear to others? Who can I be and become? And, where do I belong? To illustrate this, two brief narratives of Mary and Steve introduce the article. The making of identity, the duality of Self and Other, the gaze as a panopticon of others, identity and technology and ideas about crowdsourcing are presented and outlined, converging into the interpretive lens of crowdsourcing identities - one way to think about the making of identity when practiced in conditions mediated by contemporary digital technology.
\end{abstract}

\section{Contents}

$\underline{\text { Vignette }}$

$\underline{\text { Introduction }}$

Theme 1: Making identity

Theme 2: Identity and the duality of self and other

Theme 3: Identity and the gaze as a panopticon of evaluative others

Theme 4: I dentity and technology

Theme 5: Crowdsourcing identities

Concluding thoughts

$\underline{\text { Coda }}$

\section{Vignette}

Smiling easily, with slightly lowered eyelids, Mary looks straight into the lenses of the little device she holds at arm's length. She seems to be in her teens. Her hair curls down her neck while she tilts her head softly to the side and takes a number of pictures of herself. After carefully selecting a picture and making some adjustments, it is uploaded along with other self-portraits that she has already shared. Next to this new picture she writes, "I am a bit clueless as to how I look ... Any suggestions? Also, in which picture do you think I look 'the best'?"

In the same online context, a young man, Steve, has shared a couple of similarly composed photos. He points a handheld device at a mirror in order to display himself from various angles, poses and facial expressions. When the picture is published, he writes, "Just turned 18, wondering where I stand. How do you think I look? Please be honest." Within a few hours, both Mary's and Steve's requests have earned 


\section{I ntroduction}

The vignette presents the narratives of Mary and Steve. I often use them in writings and lectures to illustrate matters of identity and contemporary digital technology. What Mary and Steve are doing can be thought of from several perspectives. Some have emerged as fields of their own in contemporary research about social media and the practices that have spawned with uses of the Internet. For instance, matters of identity and technology has been extensively theorized in terms of the Selfie, the Persona, as Facebook identities, as open source identity, the Self as networked, as online identity, virtual identity and digital identity. In this article, I will argue that there is yet another fruitful way of thinking about identity and technology in the intuitive metaphor of crowdsourcing and I will emphasise identity as a human, existential practice about being, becoming and belonging, that may be mediated by technologies, such as social media and practiced with online crowds.

Returning to the narrative again, both Mary and Steve compose and publish carefully composed images of themselves [1], and, what is more, they have an audience in mind. They include captions in their posts, with explicit requests for feedback on appearances and after a while, there is feedback and two-way communications in commentary fields. This suggests that they use technology not only to represent and convey identity, but also, more specifically, that they use technology to engage online crowds in their making of identity. It is a practice concerning continuous requests and answers about existential matters of being, becoming and belonging. Who am I ? How do I appear to others? Who can I be and become? Where do I belong?

In this article I will outline crowdsourcing identity as a way of thinking about this particular practice. Crowdsourcing identity brings together human practices, theory and technology. It is an interpretive lens for thinking about identity as a verb, as an existential practice, extending beyond what is represented or conveyed, in conditions mediated by contemporary digital technologies. The outline of crowdsourcing identities draws on perspectives of existentialism, social constructivism, technology and ideas of crowdsourcing and it concerns a number of themes, such as the making of identity; the duality of self and other; the gaze as panopticon of evaluative others; identity and technology and crowdsourcing identity.

\section{Theme 1: Making identity}

In what ways may human identity, and the practice of making it, be considered? The meaning of identity can be thought of as socially constructed. Similar to traffic signs or the value of money or social conventions, the meaning of identity can evolve and change over time and between places and social contexts (Freidman, 1992; Burkitt, 2011; Danziger, 1997; Taylor, 1994, 1989; Seigel, 2005). Indeed, according to Hall and Du Gay (2013), the meaning of identity is placed between reversal and emergence and calls for continuous exploration.

When explored etymologically, it can be said that identity draws on the Latin word identitas, which means "the same" and thus carries connotations of relations - the same as. As described by Noonan and Curtis (2017), the meaning of identity can refer to the relation that something has to itself and the characteristics that make this thing distinct from other things. It can be summed up as A is A and not B. In that absolute sense, identity for a flower is to exist as a flower and not to exist as, for instance, a stone.

However, when thinking about human identity and departing from existentialism and social constructivism, identity refers to more than being identical and existing as something. Human identity can be understood as conditional to exist as someone, rather than as no one, and as a relational experience in the world. Drawing from Heidegger (2002), it can be said that "Everywhere, wherever and however we are related to beings of every kind, we find identity making its claim on us. If this claim were not made, beings could never appear in their Being" [2] . Furthermore, in the words of Taylor (1994), identity is a “... person's understanding of who they are, of their fundamental defining characteristics as a human being" [ $\underline{3}$ ]. According to Bauman $(2004,1996)$, "identity behaves as a verb" [4] and is put forth in relation to belonging. It is the name given to the escape sought from the uncertainties of belonging. Identity, said Bauman $(2004,1996)$, is thought of when humans are uncertain about how they are expected to place themselves and behave in order to keep existing in each other's presence. Together, these understandings suggest that identity can be a referent to being, but also to becoming and belonging. It can be thought of as a verb - a form of making - that may be practiced as humans searching for answers to continuous questions of who they are in relation to the world and others. 
I consider identity as conditional to human existence, from the notion of making, and as humans' continuous requests and answers about being, becoming and belonging. Who am I? How do I appear to others? Who can I be and become? Where do I belong? This may - or may not - be practiced in conditions mediated by contemporary digital technology.

Thinking about identity in this way can also be said to include notions of self-awareness and of a Self. Identity and the Self are, indeed, concepts that are commonly linked to each other and are sometimes used interchangeably (Owens, 2006; Oyserman, et al., 2012; Danziger, 1997). The relationship is not straightforward and is considered as one of the most "puzzling puzzles" [ $\underline{5}]$.

Notions of identity and the Self and their relation to each other are said to emerge from ancient GrecoRomans' uses of theatre masks [ $\underline{6}$ ] and from their ideas of a persona [ $]$ ] in their legal terminology (Marshall and Barbour, 2015; Burkitt, 2011; Thiel, 2011; Martin and Barresi, 2006; Arendt, 1963; Foucault, 1988). Moreover, in Arendt's (1963, 1958) discussions of politics and the human condition identities are described as “... implicit in everything somebody says and does" [8]. In that way, identity and the Self can be perceived as co-functioning, just as a theatre mask and an actor function together while performing a specific role.

Identity and the Self, whether imagined as a two-sided mask or not, are in a puzzling relationship. Identity can be supposed to have functionalities that are important for the Self. At the same time, identity and the Self can be thought of as functioning together to articulate existence as someone - rather than as no one - in the practice of making identity.

\section{Theme 2: I dentity and the duality of self and other}

Considering the making of identity as continuous requests and answers about being, becoming and belonging also implies notions of being in a world with Others. Similarly, according to Berger and Luckmann (1966), humans are said to share the reality of everyday life with Others [ 9 ]. From an existential perspective, being in the world is thought of as inescapable and being in the world inevitably includes being with Others (Heidegger, 2008). Humans are inevitably in the world; they can be lonely, but are never alone.

Being in the world with Others is also frequently conceptualized as the duality of the Self and the Other. This duality is assumed to be present in all human relations. Beauvoir (2011) wrote that the "category of the Other is as original as consciousness itself" [10] and is vital for the sense of a Self. As Sartre (1969) explained, "As I appear to the Other, so I am" [11]. Notions of the Other are defined as essential for selfawareness and are also important for humans to position and understand themselves [12] (Heidegger, 2008; Sartre, 1969; Beauvoir, 2011; Hällgren, 2015a, 2013a, 2013b; Griffiths, 1998). As such, the duality of the Self and the Other is vital in the practice of identity making.

In the work of Durkheim (1973), sense of Self is thought to be deeply rooted in social relations and in those mutual constitutional impacts that society and humans have upon each other (Durkheim, 1973; Paoletti, 2012). With reference to modern urbanization, Simmel (1950) drew on a similar duality and described the relations of society and humans' understandings of themselves, but emphasized individual agency. For instance, to maintain a sense of being and "filling a position" [13] in "metropolitan life" [14], humans have to seek attention from Others by making themselves noticeable and different.

Thoughts of the duality of the Self and the Other are present in the works of Mead (1972) and Cooley (1902). In their work, the Self is thought of as internally processed in relation to other humans, face-toface and with society as a whole. Using slightly different means and metaphors, both Mead and Cooley propose that human understandings of the Self develop symbolically through internal conversations and social interactions. Mead pictured social interactions in situations and significant or generalized Others; Cooley (1902) suggested an organic interaction between humans, who also are unseparated from society: "The object of self-feeling is affected by the general course of history, by the particular development of nations, classes, and professions, and other conditions of this sort" [15].

Identity making, as continuous requests and answers about being, becoming and belonging, can be thought of as practiced in inescapable conditions of being in the world with Others. That condition, as described earlier, has long been theorized as the duality of the Self and Other. Thinking about the making of identity as practiced in the duality of the Self and Others can also involve thoughts about values and evaluative Others [16]. As I have previously proposed (Hällgren, 2015a, 2015b, 2013a, 2013b; Hällgren, et al., 2015), the Other may appear as not only confirmative, but also as evaluative. In that way, values add to the making of identity and influence continuous questions and answers about being, becoming and belonging in normative ways.

Similarly, not only Mead and Cooley wrote about the Other as reflecting judgments in the duality of the Self and the Other, so did also Smith (1853). Smith put forth that not only "applause" [17], but also 
"censures" [18] of Others are a part of exploring the Self. Society provides a social mirror through which the Self can be seen and valued: "This is the only looking glass by which we can, in some measure, with the eyes of other people, scrutinize the propriety of our own conduct" [19]. In line with Smith's looking glass idea, Cooley (1902) spoke of "self-feeling" [20] that grows from what others socially reflect back, and that affects how the Self is perceived and judged: "Each to each a looking-glass - Reflects the other that doth pass" [21]. Further, Mead (1972) drew on dramaturgical elements to depict social interaction and theorize how humans learn about themselves from evaluative Others. For Mead, humans are thought to play roles that they shape in situations in symbolized ways and in relation to generalized and significant Others.

Furthermore, with respect to identity, Berger and Luckmann (1966) claimed, "Once crystallized, it is maintained, modified, or even reshaped by social relations" [22] and they continue that "... the individual becomes what he is addressed as by his significant others" [23]. Notions of evaluative Others are also present in Goffman (1959). With reference to social interaction and dramaturgical concepts, humans are thought of as actors who play different roles in a theatre. Goffman imagines the theatre with front and back stages. In such an arena identities are said to be performed in dramas and adjusted to the social norms of the audience.

Other ways of theorizing evaluative, normative elements in relation to identity and performance can be found in the philosophy of Butler $(1990,1988)$. With reference to gender, identity is characterized as a compelling illusion - a post-construction that evolves in what are termed performances. It is a performative accomplishment, governed by regulatory social conventions. Unlike an act in a theatre, identity is described as performed in life with "no presumption that the act is distinct from a reality" [24]

Evaluative aspects of the duality of the Self and the Other can, moreover, be diversified by theories of intersectionality. Crenshaw (1991, 1989) comprehended identity as non-essential and composed of multiple social dimensions, such as gender, race, nationality, age, class, sexuality, language, adoptive status, immigration status and physical and mental ability. Each of these dimensions relates to power and can be a part of discriminatory discourses, such as racism or sexism (Crenshaw, 1991, 1989; De los Reyes and Mulinari, 2005; Grotevant, et al., 2000; Hällgren, 2006; May, 1999; Solórzano and Yosso, 2002).

So, again, in this article the duality of the Self and the Other is argued as conditional to the practice of making identity, that is, the Other is vital to confirm existence and to continuous requests and answers about being, becoming and belonging. The Other can be confirmative and communicate approval and appreciation or there might be an absence of any recognition. Alternatively, the Other can be evaluative. The duality of the Self and the Other can involve discriminatory discourses, such as sexism and racism, and affect being, becoming and belonging so that identities are made in normative ways.

\section{Theme 3: I dentity and the gaze as a panopticon of evaluative others}

The making of identity, as continuous requests and answers about being, becoming and belonging, can be considered as conditioned by the duality of the Self and Others. However, to realize this duality, humans need to see each other, or - existentially speaking - there has to be a Gaze.

In the work of Beauvoir (2011) and Sartre (1969), the Gaze is put forth as essential to the duality of the Self and the Other. The Gaze may be experienced when humans see themselves in actual mirrors or experienced directly between humans. The Gaze may also arise indirectly, or from imagination, as part of the consciousness and so experienced as the sense of being looked at - as the thought of being observed by an imagined audience (Sartre, 1969).

From Lacan's (2010) theories about the mirror stage, as discussed in Hällgren, et al. (2015), it can be suggested that early awareness of the Gaze occurs in childhood when children between the ages of approximately 6-18 months identify themselves with their own images and realize that they can be seen by Others and looked upon as humans with their own external appearance (Lacan, 2010). Berger and Luckmann (1966) included notions of the Gaze with reference to social interaction. They noted that humans find reassurance that they really are what they think they are in "the eyes of significant others" [25].

Smith (1853) proposed that humans explore themselves "limb by limb" [르] and before a "looking-glass, or by some such expedient, endeavour, as much as possible, to view ourselves at the distance and with the eyes of other people" [27]. With reference to a "looking-glass self" [28], Cooley (1902) also stated that humans imagine how others see them when forming ideas of the Self. Similar to seeing ourselves in a mirror, ideas about the self are said to be shaped by "... the imagination of our appearance to the other person; the imagination of his judgement of that appearance ..." [29].

Power can also be involved in the experience of the Gaze. The act of looking and the duality of Self and the Other can be understood as a struggle for dominance between two consciousnesses: Who will be 
looked at - the object - and subsequently defined as the Other? Who will be the privileged subject, the one with the right to define someone as the Other? Sartre (1969) suggested that the one who finds himself being looked at has lost the struggle and has been positioned as the object.

Du Bois (1903) used the notion of the Gaze to describe how larger discriminatory structures in society that are experienced in cultural and social contexts could have an effect on the level of human selfconsciousness. He said that the “... sense of looking at one's self through the eyes of others" [30] can bring internal experiences of measuring the Self in relation to a world that looks disrespectfully on you.

In the philosophy of Beauvoir (2011), the idea of the Gaze is diversified and draws on feminine experiences of existing in the world. As I have previously discussed (Hällgren, 2015a, 2015b, 2013a), Beauvoir suggested that the Gaze communicates more than domination and objectification and that the Gaze can be intersubjective, rather than objectifying, and as such also carry friendship, agreement and love. Beauvoir said, furthermore, that men and women experience the Gaze in different ways. The female experience is not merely about interacting with the Gaze. It can also involve interactions with a "superior, male Gaze" (Beauvoir, 2011) [31].

Involvement of power in the experience of the Gaze is also theorized in the work of Foucault (1995). In his work, power is conceptualized as the panoptical Gaze - a central component in humans' power relations, disciplinary social mechanisms and individually interiorized self-regulations.

So, in this article, the Gaze is considered as more than a look. It is argued to be part of the practice of making identity because it realizes the duality of the Self and the Other. Moreover, the Gaze, present or imagined, can involve seeing the Other; it enables one to see the Self, to be seen by Others and also to see the Self through the Gaze of Others. The Gaze can therefore, additionally, reflect recognition, misrecognition or the absence of recognition. As such, the Gaze can function as a panopticon of present and imagined evaluative Others in continuous requests and answers about being, becoming and belonging. This Gaze is, furthermore, thought of as present when the making of identity is practiced in conditions mediated by contemporary digital technologies.

\section{Theme 4: I dentity and technology}

Thus far attention has been on the making of identity. In what ways can this practice relate to technology? As already noted, the meaning of identity evolves and may change over time and in social contexts. It is placed between reversal and emergence and calls for continuous exploration (Hall and Du Gay, 2013) This also applies to relations of identity and technology. Thoughts on identity and technologies have a long history. Giddens (1991), for instance, claimed that what are termed self-identities and social relations have been influenced by technologically mediated experiences since humans began to write. Foucault (1988) described ancient Greco-Roman autobiographical and reflective writings as early "technologies of the Self" [32]. At that time, the Self appeared with public and private sides, similar to a theatre mask. More recently, theories of identity have involved technologies with dramaturgical qualities, such as audiences and stages but also roles played by actors.

Other examples when technology has been thought to mediate conditions for identity are found in theories drawing on the looking glass, such as Smith's (1853) and Cooley's (1902) theorizations that the Self could be known from what Others socially reflect. Bauman $(2004,1996)$ also acknowledged a relationship between technology and thoughts on identities. For instance, in modern times, the construction of a stable and durable identity is desirable. According to Bauman $(2004,1996)$, identities are technologically mirrored and mediated in photography as carefully arranged portraits and family albums. In postmodern times, identity is described in terms such as non-fixed, multiple, shifting, negotiable and never fully finished, paralleled by technologies such as erasable and reusable videotapes and other media (Bauman, 2004, 1996; Rattansi and Phoenix, 2005)

How does identity relate to contemporary, digital technologies? There are examples of how the digitalization of society [33] has influenced thoughts on identity and the Self. For instance, in the early days of computerization and networked communication, the Self was theorized as being found in the computer. As demonstrated by Turkle (1984), the mirror was revisited and computers were conceptualized as mirrors in which humans could see themselves differently. Indeed, the computer was depicted by Turkle (1995) as a "looking glass" [34] that could be stepped through; other humans could be found on the other side of the mirror.

With a reference to actual and imagined network structures, Papacharissi (2011) suggested that social media, evolving with contemporary technologies and globalization, has become yet another space where the Self can be represented through a networked sociability that renders a networked sense of the Self. Palfrey and Glaser (2008) and Thumim (2012) stated that one of the important preconditions for a new staging of identity could be found in online access. 
Online social contexts are not only conceptualized as spaces for representing identities. They are also conceptualized as spaces for authoring, forming and performing identities. Turner (2010) emphasized that media has changed from broadcasting identities to playing a part in constructing and creating them. Drawing on examples of young women carefully presenting themselves online, Senft (2013) explains that social media can offer spaces for identities to be carefully constructed as personal brands. Senft references such forms of self-branding as a practice of microcelebrity. Rettberg (2014) analyses how selfies [35], blogs and wearable technologies propose spaces, or modes, for self-representation that are visual - written but also quantitative - and explains how these representations are used to see and shape ourselves.

One such representation, the selfie has itself emerged as a rich research field [36], where the selfie is acknowledged as provding enormous varieties, in politics, religion, sports, illness, war, crime, sexuality, pregnancy, funerals and more (Hess, 2015; Losh, 2015; Lobinger and Brantner, 2015; Rettberg, 2014; Senft and Baym, 2015; Warfield, et al., 2016). Moreover, the selfie has been theorized by Senft and Baym (2015) as a photographic object, practice and gesture that sends a message to "different individuals, communities, and audiences" [37].

Contemporary technologies are explored by Marshall (2015a, 2015b) as spaces for constructing and performing a mediatized identity, an online persona. This process can involve "monitoring and editing ourselves, connecting with strategic purpose to others and building recognizable reputations" [ $\underline{38}$ ]. With references to young people, Buckingham (2008) noted that contemporary technologies are spaces for learning that offer "new ways of forming identity, and hence new forms of personhood; and by offering communication with different aspects of the self, it enables young people to relate to the world and to others in more powerful ways" [39].

By using "Facebook identities" [눙, Loveless and Williamson (2013) pointed out that "our narrative character seems to be partly changing from a version of selfhood represented by a notion of 'inner conversation' towards a notion of selfhood represented by external interactive performance" [41]. Larsen (2016) used terms from software development and networks to theorize identity; after analyzing young people's online statements referring to emotions, she suggested that identity is staged yet also coconstructed with other young people, as an open-sourced, networked identity. Deuze (2012) theorizes media as not only constantly shaping ourselves but, also in an ontological sense, as functioning as a space for existence; humans live in, rather than with, media.

Nguyen and Barbour (2017) found that young people's selfies were essential to their "social media persona" [42], and that young people considered them "as authentic expressions of identity" [43]. With the example of the selfie, Hess (2015) pointed out that online self-representation does not exclusively operate online, but rather at the intersection of several "modes of existence" [44] and also "features the corporeal self, understood in relation to the surrounding physical space, filtered through the digital device, and destined for social networks." [45]

Taken together, technologies such as theatres, writing, mirrors, cameras, computers, digital networks and social media have inspired and continue to influence, understandings and mediations of identity in ways that are historically and socially situated. Moreover, the reversal and emergent relations of identity and technology calls for continuously explorations to recognize their contemporary reifications. I argue that there is yet another beneficial way of thinking about identity and technology in the intuitive metaphor of crowdsourcing and emphasises the necessity of understanding identity as a human, existential practice about being, becoming and belonging, that may be mediated by technologies, such as social media, and practiced with online crowds of others.

\section{Theme 5: Crowdsourcing identities}

With the diffusion of the Internet, traditional mass communication has merged with technologies that can mix one-directional with multidirectional, multimodal and asynchronous forms of communication with worldwide crowds of Others. Humans are approached with what Ellison and boyd (2013) theorized in financial terms as reshaped "economics of attention" [46]. As van Dijck (2009) similarly suggested, what used to be an informal or a momentary part of social life permeates social media and takes on new value in an economy of wider publics. Communication occurs interactively in information-rich and multimodal ways that were formerly exclusive to studios (van Dijck, 2013, 2009; Castells, 2009). Information can be articulated into composite, interactive, digital hypertexts and recombined into a whole range of cultural expressions and meanings (Markham, 2013; van Dijck, 2013, 2009).

The Internet, social networks and interactive media have brought conditions for communication that extend beyond what was available in pre-digital times [47]. Thus, humans who have access to contemporary technology, and know how to use it, can practice what Castells (2009) identified as mass self-communication - that is, sharing self-made messages with self-directed receivers in self-selected 
contexts. As such, these technologies can be used for not only mass-communication but also for mass self-communication and self-expression.

However, reshaped conditions for communication offer more than extended ways for expressing the Self. Due to their capacities for aggregation, I argue that contemporary technologies can also be used for relaying huge amounts of information about how the Self appears to Others. As narrated in the vignette of Mary and Steve, these technologies create conditions for mediating the duality of the Self and Other, as well as the Gaze. The use of the Internet, social networks and user-generated and interactive media allows not only the conveying of identities, but also for communicating, interacting and gathering information about identities. In self-produced, multimodal, multidirectional, collaborative and networked ways, humans can turn to online crowds of Others, request feedback and engage them in continuous requests and answers about being, becoming and belonging.

I argue that when humans use contemporary digital technologies to not only convey identities but also engage online crowds in requests and answers about identity, as tentatively exemplified by Mary and Steve, this practice can be considered as a form of crowdsourcing. Crowdsourcing relates to old social practices of open calls for collaboration, problem solving or information gathering on a large scale. However, contemporary technologies have extended this practice with further functionalities (Brabham, 2013). Crowdsourcing, as commonly used today, is defined as "the practice of obtaining needed services, ideas, or content by soliciting contributions from a large group of people, and especially from an online community" [48]. The conceptual use of crowdsourcing in combination with online communication was pioneered by Howe (2006), who used it to describe Web-based business models where companies shared open calls to solve a problem with a large number of individuals online. Crowdsourcing was later established empirically and theoretically by Brabham (2008) as a model for aggregation enabled by the technologies of the Internet and as a "creative mode of user interactivity, not merely a medium between messages and people" [499].

Brabham (2013) further described crowdsourcing as "an online, distributed problem-solving and production model that leverages the collective intelligence of online communities to serve specific organizational goals. Online communities, also called crowds, are given the opportunity to respond to crowdsourcing activities promoted by the organization, and they are motivated to respond for a variety of reasons" [50]. Estellés-Arolas and González-Ladrón-de-Guevara (2012) described crowdsourcing from their analyses of scholarly interpretations as "a type of participative online activity in which an individual, an institution, a non-profit organization, or company proposes to a group of individuals of varying knowledge, heterogeneity, and number, via a flexible open call, the voluntary undertaking of a task" [51]. Thus, crowdsourcing can be initiated by companies or other organizations, as well as individuals, in commercial or noncommercial means, and concerns a wide range of creative, collaborative practices in online communities.

Therefore, I argue that when humans turn to online crowds of Others and engage them in existential matters about being, belonging and becoming, the crowdsourcing practice concerns the making of identity. Digital technologies mediate extended conditions that are used for existential matters. What is more, crowdsourcing practices about identity have a theoretical resonance; that is, ideas of identity as an existential practice, technology and crowdsourcing, as outlined so far, can combine into a lens for interpretation, in this article phrased as crowdsourcing identities.

Directing this lens toward the vignette, Mary's and Steve's actions could be read as a practice of crowdsourcing identities. Furthermore, as a lens for interpretation, crowdsourcing identities may also be a way of thinking about their doings as practices where self-portraits are not only conveyed, but also combined with open implicit or explicit requests to online communities. Crowds of Others are engaged in communication and feedback about appearance, personality, social status or other identity dimensions. Further, through the lens of crowdsourcing identities, the narratives of Mary and Steve are about existence. They involve being in the world with Others, existing with contemporary digital technology that mediates conditions for the duality of the Self and Others, as well as the present or imagined panoptical Gaze from online crowds of evaluative Others that can be amplified worldwide.

\section{Concluding thoughts}

The stated purpose of this article was to outline crowdsourcing identities as one way to think about the existential practice of making identity in conditions mediated by contemporary digital technology. It started with a vignette involving Mary and Steve to exemplify how one form of the potentially very rich practice of identity making could be imagined. It was not, however, identity making per se that was narrated, but examples of how this practice could be reified and mediated by contemporary digital technologies. So, what may be concluded? First of all, identity has been subject to human thoughts for ages. It might even be as universal and original as consciousness itself, and, as such, also one condition of human existence. In this article the making of identity was argued as humans' continuous requests and 
answers about being, becoming and belonging. In that sense, it is a relational, participative practice that is essential to exist as someone, rather than as no one.

It was also held that the relation of identity and technology has been extensively theorized for a long time. Technological influences, together with societal aspects - not only economies, social structures, but also ways of thinking and how humans think about identity - are involved (Bauman, 2004; Castells, 2009; Foucault, 1988; van Dijk, 2006; McLuhan, 1964; McQuail, 2010; Turkle, 1995, 1984). Turkle (1984) said, with reference to computers, that technology affects human relationships, including what humans do and how they think about themselves. As briefly discussed in this article, the emergence of dramaturgical technologies and social practices of theatres seem to be paralleled with definitions of identity that draw on dramaturgical accessories such as masks, actors, theatre stages and audiences. Moreover, concepts such as the looking glass self, the mirror stage and self-objectification were most likely inspired by actual mirrors. Correspondingly, Bauman (1996) suggested that in modern times, concrete, steel and photographic paper paralleled notions of solid, durable identities, while in post-modern times, technologies such as biodegradable plastics and erasable, reusable videotapes and other media added to notions of identity as something impermanent. More recent examples that allude to contemporary technologies are theories of online personas, networked Selves, Facebook identities and open source identities. So, thinking about identity in relation to technology involves what has been and what is.

Relations of identity and technology could be considered, as Hall and Du Gay (2013) suggested with reference to identity, as something that is placed between reversal and emergence. Identity draws on consistency and, simultaneously, thoughts of identity may evolve in relation to emerging societal and technological conditions. Similarly, crowdsourcing identities, as one way of thinking about human identity making today, combine both consistency and emergence. Through this interpretive lens, theories of identity with a long history converge with crowdsourcing, as well as contemporary digital technologies. These technologies propose both durability and non-fixation, but also user-generated multimodal interactions with global crowds of Others, where it is possible to convey identities, gather information and practice the making of identities.

Returning to the vignette, Mary's and Steve's practices may appear to be vain and superficial. However, if they are interpreted through the lens of crowdsourcing identity, Mary and Steve are engaged in existential matters. They take advantage of contemporary digital technologies to exist as someone, rather than as no one. They publish self-portraits with requests for feedback in online and public contexts. They convey identities and gather information about identity while communicating with potentially large crowds of Others; furthermore, they engage in instant aggregations of continuous requests and answers about being, becoming and belonging. Who am I? How do I appear to others? Who can I be and become? Where do I belong?

Continuing to think about Mary and Steve through the lens of crowdsourcing identities, their posts reify and mediate a duality of the Self and the Other on a potentially worldwide scale. Mary and Steve interact with a technologically mediated Gaze, present and imagined, from global crowds of Others. This can involve seeing the Other, seeing the Self, being seen by Others and, also, seeing the Self through the Gaze of Others. Additionally, this technologically mediated Gaze may reflect recognition, mis-recognition or the absence of recognition. It may function as a panopticon of worldwide crowds of evaluative Others, present and imagined, in Mary's and Steve's continuous requests and answers about being, becoming and belonging.

The making of identity could certainly happen in other conditions and concern further dimensions of identity besides those narrated in the vignette. Technologies are not necessarily essential to identity as theorized in this article. Mary and Steve would most likely continue to engage in existential matters to exist as someone, rather than as no one, without technology.

However, if they choose to make identities in conditions mediated by contemporary digital technologies, then I argue that one way to think about it is through the interpretive lens of crowdsourcing identities, which draws on existentialism, social constructivism, technology and ideas of crowdsourcing. It brings together human practices, theory and technology, all converging themes in this article; The making of identity, The Duality of Self and Other, The Gaze as Panopticon of Evaluative Others, Identity and Technology and Crowdsourcing Identity. It is one way for thinking about digital technology, such as social media, as not only mediating conditions where identities can be represented and conveyed, but also as mediating conditions in which identities can be made. So, thinking about Mary's and Steve's practice as a form of crowdsourcing identities is one way to consider it as a technologically mediated practice about existence and not just a superficial expression of vanity. The next step is to systematically investigate whether the interpretive lens of crowdsourcing identities has deeper empirical resonance, beyond the narratives of Mary and Steve, in larger structures of social interactions about being, becoming and belonging in conditions mediated by contemporary digital technologies. 


\section{Coda}

Kim is in bed in Tokyo and Joe is on the school bus in Manchester. They skim through their social media and come across the posts from Mary and Steve. Among the many comments, there are some insensitive ones, but most are expressed as heartening emoticons and kindly written feedback such as "Every picture is a perfect picture of you", "I want your beautiful curls", "Bellissimo" or "Sooo handsome, I could drown in your dark eyes!" While Kim decides to object to an insensitive line that someone wrote in Steve's comments, Joe responds to Mary and confirms that she's amazing. A few moments later, Steve likes Kim's support, and Mary responds to Joe: "Thank you, handsome". FM

\section{About the author}

Camilla Hällgren works as an associate professor in Sweden in the Department of Applied Educational Science at Umeå University. She also works as an artist. Her internationally acknowledged artwork, which is published at www. littleswedenart.com, is represented in a large number of public institutions in Sweden. Both her academic research and artwork combine in the aim of deepen understandings of the human condition.

E-mail: Camilla [dot] Hallgren [at] umu [dot] se

\section{Notes}

1. Mary and Steve can also be said to publish images where the subject of the photograph and the photographer are the same person. In that sense, their practice exemplifies self-portrayals. Some famous examples of self-portraits from art history are Jan van Eyck (1433), Rembrandt Harmenszoon van Rijn (1661), Vincent van Gogh (1889), Frida Kahlo (1940) and Cindy Sherman (1981). A more detailed account of predigital self-portraits created by early photographers is offered by Rettberg (2014). So, what they are doing relates to an old practice that often was, and still can be, performed by whatever suitable technologies available, such as drawings, paintings, photographs, sculptures and, today; also performed by digital technologies particular to our time.

2. Heidegger, 2002, p. 26.

3. Taylor, 1994, p. 75 .

4. Bauman, 1996, p. 19.

5. James, 1950, p. 330.

6. Those theatre masks are described as inspiring the idea of a two-sided human Self. One side of the Self was thought of as a public façade that shielded the other, private, inner side - a human's true nature (Burkitt, 2011). Furthermore, the masks and their functionalities, together with notions of role-playing actors, appear in reflective writings from ancient Greece. They are used as allegory to conceptualize the "role or function that an individual human being fulfils in real life" (Thiel, 2011, p. 26). Foucault (1988) believed these reflective writings were mostly autobiographical and that the exemplifies that, the Self had become "... something to write about, a theme or object (subject) of writing activity"; moreover, these writings form early examples of "technologies of the Self" (Foucault, 1988, p. 27). Throughout history, the theatre mask has been reused to conceptualize identity, the Self and their functions. For instance, Hegel (2009) used it to describe a dual composition with a natural human being found "behind the mask of personhood" and a Self that "plays with the mask which it once puts on, in order to be its own person ..."; he also suggested that Self-consciousness is the Self that takes off the mask. The theatre mask is also used to theorize wider social phenomena and how humans relate to each other - and to whole societies. (Hegel, 2009, p. 436) For instance, Marx and Engels used the idea of a "character mask" (Marx, 1967) to point out that not only humans but governments, politicians and organisations present themselves in other ways than they really are.

7. See Marshall and Barbour (2015) for an extensive historical and etymological reading of the persona concept.

8. Arendt, 1958, p. 179.

9. Additional examples of ideas of being in the world with Others, but from different historical and intellectual contexts, can be found, for instance, in the work of Donne, Erasmus and Shakespeare. Donne (1923) poetically describes humans' involvement with each other as: "No man is an Iland, intire of it selfe; every man is a piece of the Continent, A part of the main; ..." (Donne, 1923, p. 98, italics in original) In the work of Erasmus (1511), being in the world with others is allegorically described as a theatre stage where humans live their lives and act their parts of the play. For instance, Erasmus (1511) wrote: "Now what else is the whole life of mortals but a sort of comedy, in which the various actors, 
disguised by various costumes and masks, walk on and play each one his part, until the manager waves them off the stage?". These notions of the "world as a stage" where humans play their part, is also present in Erasmus theories of human history. (Erasmus 1511/2015, p 37) Shakespeare (2004) too, drew on dramaturgical allegories and said that, "All the world's a stage/And all the men and women merely players: They have their exits and their entrances/And one man in his time plays many parts ..."

(Shakespeare, 2004, Act 2, Scene 7, p. 165) Both Erasmus and Shakespeare exemplify not only what could be interpreted as ideas of being in the world but also ideas of humans as actors in a world with others. And, with dramaturgical accessories, being in the world with others is portrayed as a theatre that humans enter and exit to play many different roles until the play is done.

10. Beauvoir, 2011, p. 24

11. Sartre, 1969, p. 237.

12. One other, much earlier example of ideas of Others' importance for learning about the Self is when Goethe (1790) said that "Only in man does man know himself; life alone teaches each one what he is" (Goethe, 1790, Act 2, Scene 3, p. 80; trans. Cooley, 1902, p. 150).

13. Simmel, 1950, p. 421.

14. I bid.

15. Cooley, 1902, p. 153.

16. Early examples of ideas of evaluative Others are found, for instance, in the work of Mandeville (1789). Referring to fame and the admiration of others and to the "Ambitious Man", he said that a human who is "conscious of having perform'd a noble Action, enjoys in Self-love, whilst he is thinking on the Applause he expects of others" (Mandeville, 1732/1962, p. 49). Humans perform in ways that are thought to be appreciated and approved by Others, and in the words of Mandeville, the thought of applause from Others inspires Self-love.

17. Smith, 1853, p. 164

18. I bid.

19. I bid

20. Cooley, 1902, p. 152.

21. I bid

22. Berger and Luckmann, 1966, p. 194.

23. I bid., p. 152.

24. Butler, 1988, p. 527.

25. Berger and Luckmann, 1966, p. 118

26. Smith, 1853, p. 163.

27. I bid.

28. Cooley, 1902, p. 152.

29. I bid.

30. Du Bois, 1903, p. 3.

31. Gendered power aspects of the experience of the Gaze are further theorized by Mulvey (2000) as the Male Gaze. In her theory, the Male Gaze is at work when women are depicted from a masculine point of view, for example, in visual arts, such as film. As a consequence, audiences of these visuals, no matter what gender they are, will experience the visuals through a male Gaze, from a masculine position.

32. Foucault, 1988, p. 27.

33. Digital technologies advanced some 60 years ago in the mid-1900s when analogue information could be converted into digital bits. It is said by McQuail (2010) that digitalisation allowed for “... information of all kinds in all formats to be carried with the same efficiency and also intermingled" (McQuail, 2010, p. 40). The increased use of digital technologies, such as the computer, made way for what Wachal (1971) called the "digitalization of society" (Wachal, 1971, p. 30). Today, digitalised networks for information exchange and social organisation, together with interactive media, have evolved as key technologies in many societies (van Dijk, 2006; Castells, 2009. 1996). Among those approximately three billion people 
who have Internet access, networked technologies have increasingly become routine so that extended possibilities to collaborate, share information and socialize have become part of ordinary, everyday activities (Lievrouw and Livingstone, 2006; Papacharissi, 2011; Siibak, 2009).

34. Turkle, 1995, p. 9.

35. The term selfie was identified among the top 10 buzzwords in 2012 (Steinmetz, 2012) and defined by Adewunmi (2013) as a cultural symbol of our time. It is a form of self-portrait that is widely published online. For instance, a September 2018 search in one of the largest online image-sharing communities, Instagram, shows that the selfie hashtag retrieves 360 million posts. Selfies are, however, more than widely published self-portraits.

36. There are ongoing, extensive, international and interdisciplinary research about the selfie phenomenon where the selfie is explored with nuanced, scientific attention and, for instance, identified as something more than acts of vanity. Examples of this can be found in the Selfies Research Network, founded 2014 by Theresa Senft (http://www.selfieresearchers.com) which gathers researchers studying the selfie and also offers scientific and educational resources. Other key sources in the research area of the selfie are a special section in the International J ournal of Communication (volume 9, 2015), where Theresa Senft and Nancy Baym bring together research from scholars in varied locations and perspectives in 19 papers, including their own introduction: (https://ijoc.org/index.php/ijoc/article/view/4067) One other key source, is the special issue on selfies, called "Me-diated inter-faces" in Social Media + Society, volume 2 (2016), edited by Katie Warfield, Carolina Cambre and Crystal Abidin (https://journals.sagepub.com/doi/abs/10.1177/2056305116641344).

37. Senft and Baym, 2015, p. 1,589.

38. Marshall, 2015b, p. 115.

39. Buckingham, 2008, pp. 13-14.

40. Loveless and Williamson, 2013, p. xi.

41. I bid.

42. Nguyen and Barbour, 2017, in the Conclusion and on pp. 9-10, in the printer friendly version of the article.

43. I bid., p. 10.

44. Hess, 2015, p. 1,629.

45. I bid.

46. Ellison and boyd, 2013, p. 160.

47. Today's online communications have developed from top-down approaches to content management that provides repositories of different kinds via bottom-up ways of managing user-produced information. The Internet changed from primarily serving as a space for passive content consumption to offering technologies that support user-generated content, global collaboration, participatory creation and social networking (O'Reilly, 2005; Anderson, 2007; Alexander, 2006). It is a shift with social significance (Downes, 2007; Ellison and boyd, 2013) and that shift has popularly been labelled as the shift from Web 1.0 to 2.0 .

48. Merriam-Webster, 2017, "Crowdsourcing".

49. Brabham, 2008, p. 87.

50. Brabham, 2013, p. xix; italics in original.

51. Estellés-Arolas and Gonzaález-Ladrón-de-Guevara, 2012, p. 11.

\section{References}

Bim Adewunmi, 2013. "The rise and rise of the 'selfie'," Guardian (2 April), at https://www.theguardian.com/artanddesign/2013/apr/02/rise-and-rise-of-the-selfie, accessed 23 September 2017.

Brian Alexander, 2006. "Web 2.0: A new wave of innovation for teaching and learning?" EDUCAUSE Review, volume 41 number 2 pp. 33-34, 36, 38, 40, 42, 44, pp. 33-44, and at https://www.educause.edu/ir/library/pdf/erm0621.pdf, accessed 23 September 2017. 
Paul Anderson, 2007. "What is Web 2.0? Ideas, technologies and implications for education," JISC Technology \& Standards Watch, at http://www. ictliteracy.info/rf.pdf/Web2.0_research.pdf, accessed 23 September 2017.

Hannah Arendt, 1963. On revolution. London: Faber and Faber.

Hannah Arendt, 1958. The human condition. Chicago: University of Chicago Press.

Zygmunt Bauman, 2004. Identity: Conversations with Benedetto Vecchi. Cambridge: Polity Press.

Zygmunt Bauman, 1996. "From pilgrim to tourist - A short history of identity," In: Stuart Hall and Paul Du Gay (editors). Questions of cultural identity. London: Sage, pp. 18-36.

doi: http://dx.doi.org/10.4135/9781446221907.n2, accessed 14 December 2018.

Simone de Beauvoir, 2011. The second sex. Translated by Constance Borde and Sheila MalovanyChevallier. New York: Vintage.

Peter L. Berger and Tomas Luckmann, 1966. The social construction of reality: A treatise in the sociology of knowledge. Hammondsworth: Penguin.

Daren C. Brabham, 2013. Crowdsourcing. Cambridge, Mass.: MIT Press.

Daren C. Brabham, 2008. "Crowdsourcing as a model for problem solving: An introduction and cases," Convergence, volume 14, number 1, pp. 75-90.

doi: https://doi.org/10.1177/1354856507084420, accessed 23 September 2017.

David Buckingham, 2008. "I ntroducing identity," In: David Buckingham (editor). Youth, identity, and digital media. Cambridge, Mass.: MIT Press, pp. 1-24.

Ian Burkitt, 2011. "Identity construction in sociohistorical context," In: Seth J. Schwartz, Koen Luyckx and Vivian L. Vignoles (editors). Handbook of identity theory and research. New York: Springer, pp. $267-283$. doi: https://doi.org/10.1007/978-1-4419-7988-9 12, accessed 14 December 2018.

Judith Butler, 1990. Gender trouble: Feminism and the subversion of identity. New York: Routledge.

Judith Butler, 1988. "Performative acts and gender constitution: An essay in phenomenology and feminist theory," Theatre Journal, Volume 40, number 4, pp. 519-531.

doi: https://doi.org/10.2307/3207893, accessed 6 October 2017.

Manuel Castells, 1996. The rise of the network society. Malden, Mass.: Blackwell.

Manuel Castells, 2009. Communication power. Oxford: Oxford University Press.

Charles Horton Cooley, 1902. Human nature and the social order. New York: C. Scribner's Sons.

Kimberle Crenshaw, 1991. "Mapping the margins: Intersectionality, identity politics, and violence against women of color," Stanford Law Review, Volume 43, number 6, pp. 1,241-1,299.

doi: https://doi.org/10.2307/1229039, accessed 6 October 2017.

Kimberle Crenshaw, 1989. "Demarginalizing the intersection of race and sex: A black feminist critique of antidiscrimination doctrine, feminist theory and antiracist politics," University of Chicago Legal Forum, volume 1989, number 1, article 8, pp. 138-167, and at http://chicagounbound.uchicago.edu/uclf/vol1989 /iss1/8, accessed 6 October 2017.

Kurt Danziger, 1997. "The historical formation of selves," In: Richard D. Ashmore and Lee Jussim (editors). Self and identity: Fundamental issues. New York: Oxford University Press, pp. 137- 159.

Paulina De los Reyes and Dana Mulinari, 2005. Intersektionalitet: Kritiska reflektioner över (o)jämlikhetens landskap. [Intersectionality: Critical reflections about the landscape of (in)equality]. Malmö: Liber.

Mark Deuze, 2012. Media life. Cambridge: Polity Press.

John Donne, 1923. Devotions upon emergent occasions. Edited by J ohn Sparrow. Cambridge: University Press.

Stephen Downes, 2007. "What connectivism is" (5 February), at https://www.downes.ca/cgibin/page.cgi?post=38653, accessed 6 October 2017.

W. E. Burghardt Du Bois, 1903. The souls of black folk: Essays and sketches. Chicago: A.C. McClurg \& Co.

Emile Durkheim, 1973. On morality and society: Selected writings. Edited and with an introduction by Robert N. Bellah. Chicago: University of Chicago Press. 
Nicole B. Ellison and danah m. boyd, 2013. "Sociality through social network sites," In: William H. Dutton (editor), Oxford handbook of Internet studies. Oxford: Oxford University Press, pp 151- 172. doi: https://doi.org/10.1093/oxfordhb/9780199589074.013.0008, accessed 14 December 2018.

Enrique Estellés-Arolas and Fernando González-Ladrón-de- Guevara, 2012. "Towards an integrated crowdsourcing definition," Journal of I nformation Science, volume 38, number 2, pp. 189-200. doi: https://doi.org/10.1177/0165551512437638, accessed 6 October 2017.

Jonathan Freidman, 1992. "The past in the future: History and the politics of identity," American Anthropologist, volume 94 , number 4 , pp. 837-859. doi: https://doi.org/10.1525/aa.1992.94.4.02a00040, accessed 6 October 2017.

Michel Foucault, 1995. Discipline and punish: The birth of the prison. Second Vintage Books edition. New York: Vintage Books.

Michel Foucault, 1988. Technologies of the self: A seminar with Michel Foucault. Edited by Luther $\mathrm{H}$. Martin, Huck Gutman and Patrick H. Hutton. Amherst: University of Massachusetts Press.

Anthony Giddens, 1991. Modernity and self-identity: Self and society in the late modern age. Cambridge: Polity Press.

Johann Wolfgang von Goethe, 1790. Torquato Tasso. Act 2, Scene 3; Antonio. Leipzig: Georg Joachim Göschen; digital version at http://www.deutschestextarchiv.de/book/view/goethe_torquato_1790 $\angle$ ?hl=Der\&p=88, accessed 6 October 2017

Erving Goffman, 1959. The presentation of self in everyday life. Garden City, N.Y.: Doubleday.

Gareth Griffiths, 1998. "Other," In: Bill Ashcroft, Gareth Griffiths and Helen Tiffin (editors). Key concepts in postcolonial studies. London: Routledge, pp. 169-173.

Harold D. Grotevant, Nora Dunbar, Julie K. Kohler and Amy M. Lash Esau, 2000. "Adoptive identity: How contexts within and beyond the family shape developmental pathways," Family Relations, volume 49, number 4, pp. 379-387.

doi: https://doi.org/10.1111/j.1741-3729.2000.00379.x, accessed 6 October 2017.

Stuart Hall and Paul Du Gay (editors), 2013. Questions of cultural identity. London: Sage.

Aaron Hess, 2015. "The selfie assemblage," International Journal of Communication, volume 9, pp. 1,629-1,664, and at http://ijoc.org/index.php/ijoc/article/view/3147, accessed 3 April 2018.

Camilla Hällgren, 2015a. "Art blended research and children's gender identity making," Creative Education, volume 6, pp. 2,333-2,350, and at http://file.scirp.org/pdf/CE_2015122214423626.pdf, accessed 6 October 2017.

doi: https://doi.org/10.4236/ce.2015.622240, accessed 6 October 2017

Camilla Hällgren, 2015b. "Be a man! Art blended research to explore boys' gender making," In: Camilla Hällgren, Elza Dunkels and Gun-Marie Frånberg (editors). Invisible boy: The making of contemporary masculinities. Umeå: Umeå University, pp. 17-30; see also http://www.invisibleboy.org, accessed 6 October 2017.

Camilla Hällgren, 2013a. "Gendered other: Hidden girl," In: Gun-Marie Frånberg, Camilla Hällgren and Elza Dunkels (editors). Invisible girl. Umeå: Umeå University, pp. 17-19; see also https://iml.edusci.umu.se/invisiblegirl, accessed 6 October 2017.

Camilla Hällgren, 2013b. “The girlish condition," In: Gun-Marie Frånberg, Camilla Hällgren and Elza Dunkels (editors). Invisible girl. Umeå: Umeå University, pp. pp. 55-63; see also https://iml.edusci.umu.se/ invisiblegirl, accessed 6 October 2017.

Camilla Hällgren, 2006. "Researching and developing Swedkid: A Swedish case study at the intersection of the Web, racism and education," doctoral thesis, Umeå University, Faculty of Teacher Education, Department of Interactive Media and Learning, at http://umu.diva-portal.org/smash /record.jsf?pid=diva2\% 3A144306\&dswid=-5602, accessed 6 October 2017.

Camilla Hällgren, 2005. “'Nobody and everybody has the responsibility' - Responses to the Swedish antiracist website SWEDKID," J ournal of Research in Teacher Education, volume 12, number 3, pp 53-77; version at http://umu.diva-portal.org/smash/record.jsf?language=en\&pid=diva2\% 3A144305\& dswid=-7744, accessed 6 October 2017

Camilla Hällgren, Elza Dunkels and Gun-Marie Frånberg, 2015. "Exploring the making of boys," In: Camilla Hällgren, Elza Dunkels and Gun-Marie Frånberg (editors). Invisible boy: The making of contemporary masculinities. Umeå: Umeå University, pp. 7-13; see also http://www.invisibleboy.org, accessed 6 October 2017. 
Georg Wilhelm Friedrich Hegel, 2009. The phenomenology of spirit: (The phenomenology of mind). Translated by J.B. Baillie. [Lawrence, Kan.]: Digireads.com Publishing.

Martin Heidegger, 2008. Being and time. Translated from the seventh German edition by John Macquarrie and Edward Robinson. New York: Harper Perennial/Modern Thought.

Martin Heidegger, 2002. Identity and difference. Translated with an introduction by Joan Stambaugh. Chicago: University of Chicago Press.

Jeff Howe, 2006. "The rise of crowdsourcing," Wired (1 June), at http://www.wired.com/wired/archive L14.06/crowds. html, accessed 6 October 2017.

William J ames, 1950. The principles of psychology. Authorized edition, unabridged. New York: Dover.

Jacques Lacan, 1977. “Mirror stage as formative of the function of the I," In: Jacques Lacan. Écrits: A selection. Translated by Alan Sheridan. New York: Norton, pp. 1-7.

Malene Charlotte Larsen, 2016. "An 'open source' networked identity. On young people's construction and co-construction of identity on social network sites," In: Michel Walrave, Koen Ponnet, Ellen Vanderhoven, Jacques Haers and Barbara Segaert (editors). Youth 2.0: Social media and adolescence. Connecting, sharing and empowering. Cham, Switzerland: Springer International, pp 21- 39. doi: https://doi.org/10.1007/978-3-319-27893-3 2, accessed 14 December 2018.

Leah A. Lievrouw and Sonia Livingstone, 2006. Handbook of new media: Social shaping and social consequences of ICTs. Updated student edition. London: Sage.

Katharina Lobinger and Cornelia Brantner, 2015. "In the eye of the beholder: Subjective views on the authenticity of selfies," International J ournal of Communication, volume 9, pp 1,848-1,860, and at http://ijoc.org/index.php/ijoc/article/view/3151, accessed 3 April 2018.

Elizabeth Losh, 2015. "Feminism reads big data: 'Social physics,' Atomism, and Selfiecity," International Journal of Communication, volume 9, pp 1,647-1,659, and at https://ijoc.org/index.php/ijoc/article Lview/3152, accessed 3 April 2018.

Avril Loveless and Ben Williamson, 2013. Learning identities in a digital age: Rethinking creativity, education and technology. London: Routledge.

Bernard Mandeville, 1962. The fable of the bees; or, Private voices, public benefits. Edited, with an introduction, by Irwin Primer. New York: Capricorn Books. doi: https://doi.org/10.1037/13124-000, accessed 14 December 2018.

Annette N. Markham, 2013. "Remix culture, remix methods: Reframing qualitative inquiry for social media contexts," In: Norman Denzin and Michael Giardina (editors). Global dimensions of qualitative inquiry. Walnut Creek, Calif.: Left Coast Press, pp. 63-81.

P. David Marshall, 2015a. "Intercommunication and persona: The intercommunicative public self," International J ournal of I nterdisciplinary Studies in Communication, volume 10, number 1, pp. $23-31$. doi: https://doi.org/10.18848/2324-7320/CGP/v10i01/53601, accessed 7 January 2018.

P. David Marshall, 2015b. "Monitoring persona: Mediatized identity and the edited public self," Frame, volume 28, number 1, pp. 115-133, and at http://www.tijdschriftframe.nl/wpcontent/uploads/2017/08 LFrame-28_1-Monitoring-Persona.pdf, accessed 7 January 2018.

P. David Marshall and Kim Barbour, 2015. “Making intellectual room for persona studies: A new consciousness and a shifted perspective," Persona Studies, volume 1, number 1, at https://ojs. deakin. edu.au/index.php/ps/article/view/464/489, accessed 7 January 2018. doi: https://doi.org/10.21153/ps2015vol1nolart464, accessed 14 December 2018.

Raymond Martin and John Barresi, 2006. The rise and fall of soul and self: An intellectual history of personal identity. New York: Columbia University Press.

Karl Marx, 1967. Capital: A critique of political economy. Translated from the third German edition by Samuel Moore and Edward Aveling, edited by Frederick Engels. New York: International Publishers.

Stephen May, 1999. "Critical multiculturalism and cultural difference: Avoiding essentialism," In: Stephen May (editor). Critical multiculturalism: Rethinking multicultural and antiracist education. London: Falmer Press, pp. 11-41.

Marshall McLuhan, 1964. Understanding media: The extensions of man. New York: McGraw-Hill.

Denis McQuail, 2010. McQuail's mass communication theory. Sixth edition. London: Sage. 
George Herbert Mead, 1972. Mind, self, and society: From the standpoint of a social behaviorist. Edited and with an introduction by Charles W. Morris. Chicago: University of Chicago Press.

Merriam-Webster Dictionary, 2017. "Crowdsourcing," at https://www. merriam-webster.com/dictionary Lcrowdsourcing, accessed 21 September 2017.

Laura Mulvey, 2000. "Visual pleasure and narrative cinema," In: Robert Stam and Toby Miller (editors). Film and theory: An anthology. Malden, Mass.: Blackwell, pp. 483-494.

Linh Nguyen and Kim Barbour, 2017. "Selfies as expressively authentic identity performance," First Monday, volume 22, number 11, at http://firstmonday.org/ojs/index.php/fm/article/view/7745/6561, accessed 7 January 2018.

doi: http://dx.doi.org/10.5210/fm.v22i111.7745, accessed 14 December 2018.

Harold Noonan and Ben Curtis, 2014. "Identity," Stanford Encyclopedia of Philosophy (25 April), at https://plato.stanford.edu/archives/spr2017/entries/identity/, accessed 6 October 2017.

Tim O'Reilly, 2005. "What Is Web 2.0: Design patterns and business models for the next generation of software" (30 September), at http://oreilly.com/web2/archive/what-is-web-20.html, accessed 6 October 2017.

Timothy J. Owens, 2006. "Self and identity," In: John Delamater (editor). Handbook of social psychology. Boston, Mass.: Springer, pp. 205-232. doi: https://doi.org/10.1007/0-387-36921-X 9, accessed 6 October 2017.

Daphna Oyserman, Kirsten Elmore and George Smith, 2012. "Self, self-concept and identity," In: Mark R. Leary and J une Prince Tangney (editors). Handbook of self and identity. Second edition. New York: Guilford Press, pp. 69-104.

J ohn Palfrey and Urs Gasser, 2008. Born digital: Understanding the first generation of digital natives. New York: Basic Books.

Giovanni Paoletti, 2012. "Durkheim's ‘Dualism of human nature': Personal identity and social links," Durkheimian Studies, volume 18, pp. 61-80.

doi: https://doi.org/10.3167/ds.2012.180105, accessed 6 October 2017.

Zizi Papacharissi (editor), 2011. A networked self: Identity, community and culture on social network sites. New York: Routledge.

Ali Rattansi and Ann Phoenix, 2005. "Rethinking youth identities: Modernist and postmodernist frameworks," Identity, volume 5, number 2, pp. 97-123.

doi: https://doi.org/10.1207/s1532706xid0502_2, accessed 22 April 2018.

Jill Walker Rettberg, 2014. Seeing ourselves through technology: How we use selfies, blogs and wearable devices to see and shape ourselves. New York: Palgrave Macmillan. doi: https://doi.org/10.1057/9781137476661, accessed 3 April 2018.

Theresa M. Senft, 2013. "Micro celebrity and the branded self," In: John Hartley, Jean Burgess and Axel Bruns (editors). A companion to new media dynamics. Blackwell, pp. 346-354. doi: https://doi.org/10.1002/9781118321607.ch22, accessed April 32018.

Theresa M. Senft and Nancy K. Baym, 2015. "What does the selfie say? I nvestigating a global phenomenon," International Journal of Communication, volume 9, pp. 1,588-1,606, and at http://ijoc.org Lindex. php/ijoc/article/view/4067/1387, accessed April 32018.

Jean-Paul Sartre, 1969. Being and nothingness: An essay on phenomenological ontology. Translated by Hazel E. Barnes. University Paperbacks (UP), 326. London: Methuen.

Jerrod Seigel, 2005. The idea of the self: Thought and experience in western Europe since the seventeenth century. Cambridge: Cambridge University Press. doi: https://doi.org/10.1017/CBO9780511818141, accessed 6 October 2017

William Shakespeare, 2004. >As you like it. Edited by Cynthia Marshall. New York: Cambridge University Press.

Andra Siibak, 2009. "Self-presentation of the 'Digital Generation' in Estonia," Ph.D. thesis, University of Tartu (25 August), at http://hdl.handle.net/10062/10593, accessed 6 October 2017.

Georg Simmel, 1950. "The metropolis and mental life," In: Georg Simmel. The sociology of Georg Simmel. Translated, edited, and with an introduction by Kurt H. Wolff. Glencoe, III.: Free Press, pp. 409-424.

Adam Smith, 1853. The theory of moral sentiments. New edition, with a biographical and critical memoir 
of the author, by Dugald Stewart. London: H. G. Bohn.

Katy Steinmetz, 2012. "Selfie," Time (4 December), at http://newsfeed.time.com/2012/12/04/top-10news-lists/slide/selfie/, accessed 6 October 2017.

Daniel G. Solórzano and Tara J. Yosso, 2002. "Critical race methodology: Counter-storytelling as an analytical framework for education research," Qualitative Inquiry, volume 8, number 1, pp. 23-44. doi: https://doi.org/10.1177/107780040200800103, accessed 6 October 2017.

Charles Taylor, 1994. Multiculturalism: Examining the politics of recognition. Edited and introduced by Amy Gutmann. Princeton, N.J .: Princeton University Press.

Charles Taylor, 1989. Sources of the self: The making of the modern identity. Cambridge, Mass.: Harvard University Press.

Udo Thiel, 2011. The early modern subject: Self-consciousness and personal identity from Descartes to Hume. Oxford: Oxford University Press. doi: https://doi.org/10.1093/acprof:oso/9780199542499.001.0001, accessed 6 October 2017.

Nancy Thumim, 2012. Self-representation and digital culture. Houndmills, Basingstoke, Hampshire: Palgrave Macmillan. doi: https://doi.org/10.1057/9781137265135, accessed 6 October 2017.

Sherry Turkle, 1995. Life on the screen: Identity in the age of the Internet. New York: Simon and Schuster.

Sherry Turkle, 1984. The second self: Computers and the human spirit. New York: Simon and Schuster.

Graeme Turner, 2010. Ordinary people and the media: The demotic turn. Los Angeles, Calif.: Sage.

Robert Wachal, 1971. "Humanities and computers: A personal view," North American Review, volume 256, number 1, pp. 30-33, and at http://www.jstor.org/stable/25117163, accessed 6 October 2017.

Jan A.G.M. van Dijk, 2006. The network society: Social aspects of new media. Second edition. London: Sage.

José van Dijck, 2013. The culture of connectivity: A critical history of social media. New York: Oxford University Press.

José van Dijck, 2009. “Users like you? Theorizing agency in user-generated content," Media, Culture \& Society, volume 31, number 1, pp. 41-58. doi: https://doi.org/10.1177/0163443708098245, accessed 6 October 2017.

Katie Warfield, Carolina Cambre and Crystal Abidin, 2016. "Introduction to the Social Media + Society special issue on selfies: Me-diated inter-faces," Social Media + Society, volume 2, number 2. doi: https://doi.org/10.1177/2056305116641344, accessed 3 April 2018.

\section{Editorial history}

Received 7 October 2017; revised 27 April 2018; revised 16 October 2018; revised 28 November 2018; accepted 28 November 2018.

Copyright (c) 2019, Camilla Hällgren. All Rights Reserved.

Crowdsourcing identities: On identity as an existential practice mediated by contemporary digital technology

by Camilla Hällgren.

First Monday, Volume 24, Number 1 - 7 January 2019

https://journals.uic. edu/ojs/index. php/fm/rt/printerFriendly/8112/7706

doi: http://dx.doi.org/10.5210/fm.v24i1.8112 